\title{
The study of theology and religion at the University of Pretoria: Two epochs of endeavor
}

\begin{tabular}{|c|c|}
\hline $\begin{array}{l}\text { Author: } \\
\text { J. S. (Kobus) K }\end{array}$ & rüger ${ }^{1}$ \\
\hline $\begin{array}{l}\text { Affiliation: } \\
{ }^{1} \text { Department } \\
\text { and Christian } \\
\text { of Theology, } \\
\text { Pretoria, Sout }\end{array}$ & $\begin{array}{l}\text { of Dogmatics } \\
\text { Ethics, Faculty } \\
\text { Iniversity of } \\
\text { h Africa }\end{array}$ \\
\hline $\begin{array}{l}\text { Research Proj } \\
\text { Project Leade } \\
\text { Project Numk }\end{array}$ & $\begin{array}{l}\text { ect Registration: } \\
\text { r: J. Buitendag (1) } \\
\text { er: } 02402343\end{array}$ \\
\hline $\begin{array}{l}\text { Description: } \\
\text { Prof. Dr Kobus } \\
\text { participating i } \\
\text { project, 'Univ } \\
\text { and Theology } \\
\text { Prof. Dr Johan } \\
\text { Departement } \\
\text { and Christian } \\
\text { Dean, Faculty } \\
\text { University of }\end{array}$ & $\begin{array}{l}\text { Krüger is } \\
\text { n the research } \\
\text { ersity, Education } \\
\text {, directed by } \\
\text { Buitendag, } \\
\text { of Dogmatics } \\
\text { Ethics, and } \\
\text { of Theology, } \\
\text { retoria. }\end{array}$ \\
\hline $\begin{array}{l}\text { Correspondin } \\
\text { Kobus Krüger, } \\
\text { jskruger@mys }\end{array}$ & $\begin{array}{l}\text { g author: } \\
\text { ticism.co.za }\end{array}$ \\
\hline $\begin{array}{l}\text { Dates: } \\
\text { Received: } 28 \\
\text { Accepted: } 04 \\
\text { Published: } 27\end{array}$ & $\begin{array}{l}\text { Apr. } 2017 \\
\text { June } 2017 \\
\text { July } 2017\end{array}$ \\
\hline $\begin{array}{l}\text { How to cite th } \\
\text { Krüger, K.J.S., } \\
\text { study of theol } \\
\text { religion at the } \\
\text { Pretoria: Two } \\
\text { endeavor', HT } \\
\text { Studies/Theol } \\
73(1), \text { a } 4615 . \\
\text { org/10.4102/ }\end{array}$ & $\begin{array}{l}\text { is article: } \\
\text { 2017, 'The } \\
\text { ogy and } \\
\text { University of } \\
\text { epochs of } \\
\text { S Teologiese } \\
\text { ggical Studies } \\
\text { https://doi. } \\
\text { tts.v73i1.4615 }\end{array}$ \\
\hline $\begin{array}{l}\text { Copyright: } \\
\text { @ 2017. The } A \\
\text { Licensee: AOS } \\
\text { is licensed unc } \\
\text { Creative Comr } \\
\text { Attribution Lic }\end{array}$ & $\begin{array}{l}\text { Iuthors. } \\
\text { IS. This work } \\
\text { der the } \\
\text { nons } \\
\text { ense. }\end{array}$ \\
\hline Read online: & \\
\hline 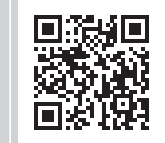 & $\begin{array}{l}\text { Scan this QR } \\
\text { code with your } \\
\text { smart phone or } \\
\text { mobile device } \\
\text { to read online. }\end{array}$ \\
\hline
\end{tabular}

\begin{abstract}
This article explores the possibility of an alignment of (a) theology (understood as study concentrating on one faith from the faith suppositions of that faith) and (b) a study of world religions, open to all regardless of faith in the context of an encompassing theory. This article argues that far from undermining the dignity and value of any religion, (b) could add value to the theological study of any one religion. This article proceeds to develop a model for (b). Utilising a methodology revolving around the strategies of careful historical criticism, faithful intentional understanding and imaginative yet trustworthy tendentional interpretation, this article explores a model harmonising the key concepts of metaphysical mysticism (understood as the peak of religious aspiration), conditionality (emphasising the unique singularity of individual religions), totality (emphasising the religious landscape as one coherent whole) and horizon (emphasising the non-absoluteness of all religions, petering out on, and arising from, silence).
\end{abstract}

\section{Introduction}

May I extend my sincere appreciation to Professor Buitendag, the teaching and administrative staff of the faculty and its student body, as well as the university for taking the major step of consciously entering a new epoch in the history of the faculty. Presupposing and extending the argument of a previous article on the past century of the faculty (Krüger 2016) shall now peer ahead at such a possible new epoch. That future will not start in 2018, but has already begun. Indeed, one's understanding of the past is conditioned by one's anticipating understanding of the future, and vice versa. The opening of a gate and leaving it open suggests a deliberate choice, a thoughtful movement from one place to another, from a past into a future, from a known inside to an as yet perhaps unknown outside - yet each implying the other.

Open gates in the case of the faculty, leading in which direction, giving access to what? Where does the phrase '. . . and Religion' in the name of the faculty as from 2018 lead to? I am now not taking a position in the 'Theology ...' part of the new faculty and not taking part in a perfectly legitimate Christian theologia religionum exercise, but engaging in an argument in the '. . . and Religion' addition to the new faculty: An open forum out there where Christians, Jews, Muslims, non-theists and so on will meet and mingle as free, empowered, thinking equals and discuss issues concerning the meaning of human existence on planet Earth. Yet I submit that such a new leg of the faculty will have an impact on the manner of moving of the first leg and the way of walking of the faculty as a whole.

One is reminded of a huge mountain range, say the Himalayas. On the foothills and in the valleys lie the villages where people are born, live and die. That is where the religions with their institutions, serving the communities and assisting people to live and die with dignity and meaning, are situated. At the very top are remote yet massively present peaks, perhaps 10 or 12 such awe-inspiring minds surrounded by lesser mountains, piercing the empty sky where the air is thin, and overlooking and integrating an enormous landscape. Yet even their vision is surrounded by an ever-receding, unreachable, uncrossable horizon. On the steep, difficult and often slippery slopes between the solitary peaks and the villages with their laughing and crying are the levels of intellectual labour. There, trying to link the visions of infinite sky above and the smoke from hearths below, labour and clamber the religious intellectuals: The apologists, defenders and sometimes reformers of religious institutions. It is impossible to separate these three altitudes. In a sense village life comes first and last, but so do the peaks of the one mountain range. Without them, there would be no foothills and valleys. May the new epoch embarked upon

Note: Article read at Faculty of Theology Centenary Conference, 5-6 April 2017, Conference Gateway to the Future from a Deconstructed Past. 
by the faculty connect the various religious villages and help to achieve a pax fidei (to quote Nicholas of Cusa 1990). May it give access to various mountains in the one range for those students and other seekers in the wider public domain who wish to go there, perhaps to scale one or more of them. May they come back better servants of humanity and the world. That is my wish for the faculty.

\section{Methodological guidelines}

Is it possible at all to traverse these daunting distances horizontally and vertically, visit various villages, at least see and respect other mountains than ones' own? How may the faculty go about providing maps and skills to explore this beautiful wilderness of an inclusive past and an inclusive future? Allow me to mention three significant guidelines, two of which are widely utilised in the study of religions, the third perhaps more contentious.

\section{Historical-critical explanation}

This refers in the broadest sense to the explanation of relevant facts from the past and present pertaining to any religious group, person, doctrine, tradition and so on, and presenting such facts as correctly and wisely as possible, taking into account the full conditionalistic complexity of historical situations. Such explanation investigates how all religious constructs link up with the social contexts, the historical backgrounds and contextual circumstances from which they arose. Finality of explanation can neither be claimed nor sought. No historical picture, whether loyalist or critical, is ever wholly 'correct'. After all, every explanation of the past is a construction by the present with a view to the future, a present and future which will in due time be the past itself. Yet caricatures, whether wilfully or ignorantly, propagandistically or defensively drawn, are taboo.

\section{Intentional Understanding}

This refers to understanding in a broad phenomenological sense. The scholar of religion as a generic phenomenon and religions as historical manifestations of it endeavours to be true to the true intentions of all authors and books and traditions and believers of the past and the present. One should strive to adequately understand (as if from an insider's point of view) and respect what the original initiators of traditions and the authors of religious books and faithful participants in rituals subjectively experienced and intended in the past, and experience and intend in the living present as human beings all sharing the same mental structure as members of the same biological species. Visiting the sacred ground of others, the respectful visitor, albeit still a stranger, will take off his shoes, and as understanding grows, acceptance grows.

\section{Tendentional Interpretation}

This refers to the imaginative yet trustworthy interpretation of what I would call the tendentional drift of all religions in the same direction, like swallows flying north in autumn from here. It presupposes the negation of all superficial attempts to leap across categories such as historical connectedness, comparability and compatibility to sameness and even identity. The art of creative interpretation consists in combining a profound appreciation of the uniquely particular within the universal, which is something quite different from a facile ecumenism claiming that all boil down to the same thing. It refuses to flatten out all real differences in adaptation to the requirements of global consumer society, even in academic garb. Suspecting and exploring unrealised continuities, tendentional interpretation does not amount to a tendentious superimposition of one's personal whims on the religious material, but proceeds from taking the truth claims of all religions very seriously indeed. Then go as far as can be gone and all religious words, conceptual systems, symbols and myths and institutional arrangements peter out where silence is the only adequate response.

\section{Theoretical postulates}

Extending the above, the following four cornerstones of a theoretical map of religions announce themselves.

\section{Metaphysical mysticism}

I would look at the future of the 'religion' part of the faculty in terms of what I would call 'metaphysical mysticism': not quite rational 'metaphysics' or 'theology'; not quite mere pious spiritual feelings of rapture or unity either; and not a variety of social studies, reducible to or a mixture of sociology or psychology of religion, or history of religions, or political studies or social work. Rather, it refers to a kind of thought and insight into, an understanding of, reality: transcending, radicalising, relativising yet appreciating all constructions of the meaning of things, to which practical expression of such insight in the form of attitudes, emotions, thinking patterns, words and institutions are added in religions. The term 'metaphysical mysticism' refers not to any academic paradigmatic 'theology', 'philosophy' or 'religious studies', but to a dimension transcending them. It refers to the study of the separate peaks of the one mountain range of religion. And yet a community of kindred spirits is discovered. Let us indulge in an experiment: In an imagined conversation of the sort pictured by Plato in his dialogues, participated in by men and women such as Jesus and Hadewijch, Lao-tzu and Chuang-Tzu, an anonymous Upanishadic visionary and Sankara, Siddhartha and Fa-tsang, Rabea and Rumi and others, I do not imagine any one claiming absolute truth exclusively and demanding submission of all the others. I imagine such women and men to be clothed with quiet dignity and inner authority but not bedecked with power, conversing amicably and lightly in gentle voices, not triumphantly, and between and in their words a noble, shared silence. Indeed, peaks of the spirit, with warm, humane hearts.

\section{Conditionality}

Causality ('what, or w[W]ho, causes what, and how?') has always interested humankind as of central significance. I utilise a concept borrowed from early Buddhism, translatable 
as 'conditionalism' (Narada 1992a; Narada 1992b; 1993; Nyanatiloka 1980, pp. 139-145). This denotes more than linear causality between A and B. It intends complex, multifactorial sets of mutually inherent, reciprocally active factors and circumstances. All things, seemingly so selfcontained, are each a composite package in itself, and related to other packages in relationships of constant receiving and giving. The notions of constant change, impermanence and contingency announce themselves. All things are mutually implicit, mutually conditioning, like the fingers of one's hand: cut off the thumb, and the little finger is no longer what it was. Each individual thing is a temporary arrangement in ever changing larger sets of conditioning and conditioned circumstances.

Let me push our earlier analogy a bit further. To the ancients in India, the Himalayan range was a symbol of eternal, unchanging being. Today we know of their historicity, their being the result of the meeting of drifting continents. Likewise, in the field of religion, there are the great shuddering events of the meeting of continents of meaning, the grinding, the pushing up of new mountains of the spirit. Being historical events, they are not eternal. Eventually they are worn down, could become flatlands, even be submerged under the ocean. That is in the nature of all things. With due respect to the great bishop of Hippo: every concept of a civitas Dei (Augustine 2009) is a construct, has a beginning and an end. In terms of a perspective of the formation, drift and meeting of religious continents, I am particularly interested in the encounter of Christianity and Buddhism. The message of Jesus happened to have been given theoretical, theological shape conditionalistically by means of the hallowed Western philosophies of Plato and Aristotle. But conduct the mental experiment of imagining what might have happened if his followers were handed the toolbox of, say, Buddhist philosophy. Is it possible that the meeting of various religious continents today, including (to refer to our specific context) African religion, may also result in the creation of new mountain ranges?

\section{Totality}

The five fingers together form the total hand, total hand becomes total body and so on and so on, forming organic wholes of increasing size and complexity, ad infinitum. Yet all of this implies a profound appreciation of, respect for, each event in its unique singularity. There is no fall-back option of eternal stability. By 'totality', I strictly do not understand 'unity' either of the exclusive or the coercive inclusive sort, but mutuality, light coherence, peace - discussed by Cusanus in his book. But even closer to the impulse of this theoretical orientation stands the earlier figure of Roman scholar-theologian-politician Boethius (c 480-525) when he, probably when his execution was imminent, in his De consolatione philosophiae sought an inclusive wisdom (Boethius 1981). As his world imploded, he reached out to openness in a complex train of thought, without abandoning Christianity. Indeed, belonging in love and loyalty to a specific religion does not preclude one from being a 'metaphysical mystic' in the sense intended here.
This approach affirms the solidarity of all of humankind and all its religions, and disapproves of any attempt to isolate any religion from that inclusive social and historical context, attempting to absolutise any one. The dynamic reality of cross-religious inter-connections should not be a secondary afterthought, but a primary point of departure of the study of any one particular religion. A healthy gait of the faculty would require the study of the relatively particular and the universal moving in partnership, like two strong, mutually supportive legs.

Let us not pursue lame sameness of religions, but creative synopsis, for example, by seeking the company of a number of extremely gifted and creative minds, visionaries once in a while tilting religions and even cultures, and each one of them part of a living, conditionalistic totality. I cannot resist adding a few names to the ones mentioned earlier in this conversation of ours: in East-Asia, Dogen; in India, Nāgārjuna, Vasubandhu, Mira Bai and visionary thinkers in modern India, such as Vivekananda and Aurobindo; in pre-Christian Hellenic Europe, Heraclitus, Parmenides, Pythagoras, Empedocles and the Stoics; in Judaism, Philo, Isaac Luria and Spinoza; in Christianity and the West, Plotinus and Proclus, Hildegard of Bingen and Johannes Ruusbroec and Meister Eckhart; in Islam, Mansur al-Hallaj and Ibn Arabi; and non-aligned ones such as Kabir. Like Kabir, the wandering traveller on the journey of this kind might neither avoid nor settle in any camp, but move appreciatively through and beyond each occurring on his path. In doing so, the roamer, extending friendship to all, might move on, fascinated by the empty horizon, yet always appreciating the conditionalistic landscape in its fullness. These women and men did not exactly make it to the list of top sellers of their times, and would probably not have made the hit parade in the present global business enterprise of academic knowledge production. They would not have minded. Socially speaking, in terms of the power structures of their day, they were mostly, perhaps essentially, marginal figures, outsiders.

Further back, there are the traditional and primal religions of humankind, dating back tens of thousands of years. In Africa, the scholar of religion has the good fortune of working in such an ancient living context of culture and religion with its unique contribution to the religious landscape.

\section{Horizon}

In the end, the buck is here not seen to stop with some eternal cause or substantial being, as Aristotle and Thomas thought, or with eternal Atman or some necessary thing-in-itself. All totalities, all being conditioned, all theologies and their projected eternal referents peter out on absolute horizon, on which they also appear. The word sounds on the edge of unsound. Yet far from being defeatist and nihilist, this perspective urges the radicalisation of all such systems: they are all surrounded, permeated, by Horizon, and eventually emptied yet also embraced. They are not all necessarily consciously, intentionally, oriented towards Horizon, but deep down, tendentionally, I would suggest, they all long for 
that ultimate, absolute Horizon. In the language of one of the great scriptures of the world, the Heart Sutra (there are numerous English translations, including Lopez 1988): form is emptiness. This is something more - or rather, less - than, for example, Christian apophatic theology or apophatic mysticism. But then the Heart Sutra continues: emptiness is form. Embrace, love the world in all its richness, also the richness of its religious and metaphysical mystical heritages.

Precious is the more than two millennia old religion of Christianity, are the churches constituting this faculty, is the theological enterprise taking shape at the University of Pretoria in challenging circumstances - precious not in spite of its unique contingency, but because of that, in the context of the whole body of historical totality, including all religions, surrounded by a horizon where silence is appropriate. That, I submit, is the context of the study of the Christian as of every other faith today, tomorrow and next year, challenging it radically, that is, uncovering its roots promising a sturdy trunk and growth towards the open sky, stretching and reaching far and wide and providing beauty, shelter and nourishment to all life.

\section{Acknowledgements Competing interests}

The author declares that he has no financial or personal relationships which may have inappropriately influenced him in writing this article.

\section{References}

Augustine, S., 2009, De civitate Dei; edited, with an introduction, translation and commentary by $P G$ Walsh, Aris and Philips, Warminster.

Boethius, 1949, Trost der Philosophie: Lateinisch und Deutsch, Artemis-Verlag, Zürich.

Krüger, J.S., 2016, 'The study of religion and theology at the University of Pretoria - A century of endeavour in conditionalistic perspective', HTS Teologiese Studies/ Theological Studies 72(4), a3575. https://doi.org/10.4102/hts.v72i4.3575

Lopez, D.S., 1988, The Heart Sutra explained: Indian and Tibetan commentaries, State University of New York Press, Albany, NY.

Narada, U., (Mula Patthana Sayadaw), 1992a, Conditional relations (Pațthāna) I, Pali Text Society, Oxford.

Narada, U., (Mula Patthana Sayadaw), 1992b, Conditional relations (Pațthāna) II, Pali Text Society, Oxford.

Nicholas of Cusa, 1990, Nicholas of Cusa on interreligious harmony: Text, concordance and translation of De pace fidei, Edwin Mellen, New York.

Nyanatiloka, T., 1980 (1952), Buddhist dictionary. Manual of Buddhist terms and doctrines, Buddhist Publication Society, Kandy. 